\title{
From gathering to discard and beyond: Ethnoarchaeological studies on shellfishing practices in the Solomon Islands
}

\author{
Annette 0ertle and Katherine Szabó
}

\section{Introduction}

Shell-bearing archaeological sites in tropical island environments are subject to various environmental and human influences, which affect how a site forms and transforms over time. The immense range of species diversity in the tropical Indo-Pacific marine province means that marine subsistence practices may vary between different environmental zones and groups of people. Shellfish are an important coastal resource that is relatively low cost to gather and process. Island Melanesia is rich in zones of mangrove forest, intertidal rocky shore, sandy beaches and reefs, all of which support certain species of shellfish that can be used for food or raw materials for artefact production.

The practice of shellfishing is complex in nature with a huge range of shell species and a variety of gathering practices based on habitat, location, time of day and individual human behaviours. Additionally, cooking techniques and discard patterns can also vary from one site to another. Varying processing methods and discard patterns affect the preservation of shell and the formation of a site (Claassen 1998). Overall, it can be difficult to truly understand the various levels of behaviour that led to the incorporation of shell into the archaeological context (sensu Schiffer 1972). Ethnoarchaeology, which consists of undertaking fieldwork as a participant observer and documenting the way the archaeological record is formed in specific human groups (Davidson 1988), is one of the tools used by archaeologists to piece together information about shell gathering, processing and disposal methods. This chapter will detail such an ethnoarchaeological approach for studying shell material in the tropical Indo-West Pacific. Such data can provide the information needed to make inferences about the systemic context from which the shell material originally came.

Firstly, we will outline key ethnographic and ethnoarchaeological studies on shellfishing in the Pacific and discuss issues of linking modern human behaviour to archaeological material. Ethnoarchaeological fieldwork on the island of Malaita in the Solomon Islands, undertaken to record traditional shellfish gathering, processing and discard practices, will then be detailed. Comparing the data acquired with previous studies in Island Melanesia shows some similarities in gathering behaviours; however, new data on processing and discard show the importance of 
considering these steps as part of the story and how specific behaviours impact shell preservation and site formation. Previous ethnographic studies in the Indo-Pacific primarily focus on gathering practices (Meehan 1982; Thomas 2002) and the role of women and children (Bird and Bird 2000; Jones 2009). Although processing and discard practices have been considered, they have not formed the focus of any particular study. This study aims to fill this void by understanding each step, from the systemic environment from which the shells are collected to the archaeological context into which they are introduced (Figure 10.1).

Systemic Context

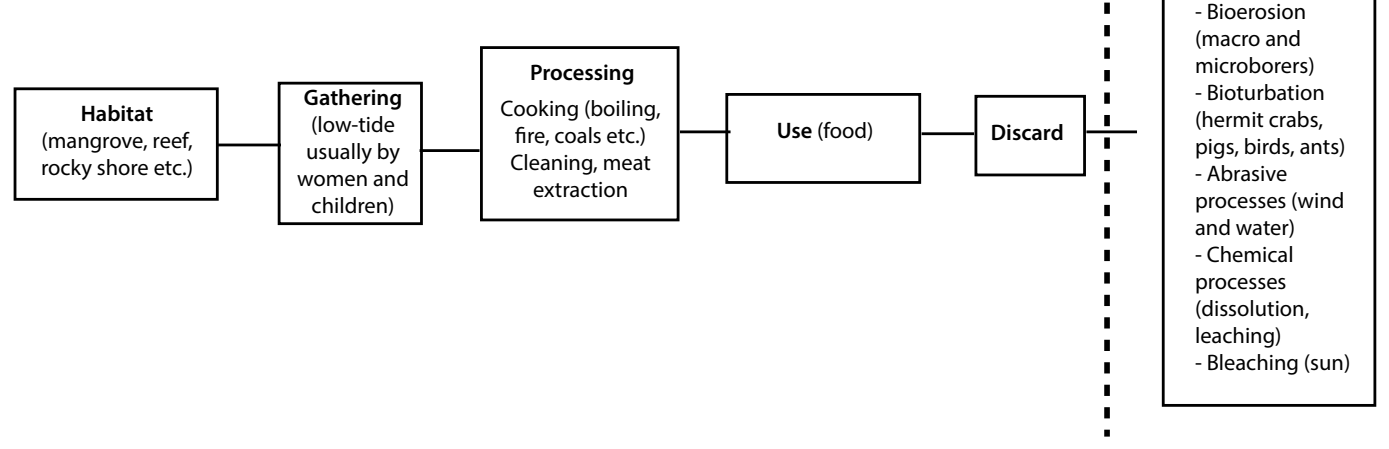

Figure 10.1. Systemic to archaeological context of shellfishing (after Schiffer 1972).

Source: Annette Oertle.

\section{Ethnoarchaeology as a link between past and present}

In the Indo-Pacific, ethnographic shellfishing studies have primarily been undertaken in the more recent past, as is clear from Waselkov's (1987) in-depth survey on ethnographic shellfishing. Focused ethnographic and ethnoarchaeological studies on shellfishing are few and tend to focus on particular aspects of shellfishing practices (Bird and Bird 2000; Carter 2014; Malm 2009; Meehan 1982; Swadling and Chowning 1981; Thomas 2002). These recent ethnographic studies provide valuable data on modern behaviours in these regions, but the lack of information on the behaviours associated with processing and disposing of shellfish is something that needs to be addressed to maximise their usefulness for archaeology. Inferences about past human behaviours based purely on ethnographic studies can be questionable even with the inclusion of each pre-depositional stage (see Wylie 1985), and especially when the practices of one cultural group in the present are seen as sufficient to interpret those of an unrelated (or even related) group in the past.

O'Connell (1995) highlights the complexity of archaeological interpretations based upon ethnoarchaeological research on faunal remains. Interpretations about site structure and faunal remains need to take into account the unpredictability of behaviour. For example, the transport of body parts can vary situationally, and various agents can cause similar patterns of damage on bone (O'Connell 1995). Consideration of seasonality is also an important factor, as certain species may be collected during particular seasons and specific habitats targeted based upon tidal range (Jimenez et al. 2011); for example, the active collection of reef resources during spring tides (de Boer et al. 2002). Continuity of behaviours and assumptions regarding the scale of site 
formation are the primary issues faced when dealing with ethnoarchaeological research. Faulkner (2006:11) highlights the problems with using ethnographic data from distinct areas to interpret a range of archaeological data in Australian archaeology. This introduces a simplistic and limiting view of human-environment interactions, reiterating the main issue of using ethnography to interpret archaeological data: it tends to assume continuity between the recorded ethnographic present and behaviours in the past (Faulkner 2006:11). Nevertheless, ethnoarchaeology can provide insights into how various external factors may impact human behaviours. 'Ethnoarchaeological studies have greatly increased our sensitivity to the diverse environmental and cultural factors that can affect or determine the nature of the static archaeological remains that we recover' (Sinopoli 1991:177).

Ethnoarchaeology can also be a component of the 'slow science' approach to archaeology where a greater focus on ethics, social engagement and critical reflections on power relations are made (Cunningham and MacEachern 2016). We approach ethnoarchaeology as a 'research strategy framed within different theoretical structures' (Politis 2016:705) through the use of an array of methods and recording techniques. Although there has been much in the way of specialised literature and debate around the use of ethnographic analogy and ethnoarchaeology within archaeological interpretation (David and Kramer 2001; Gould and Watson 1982; O'Connell 1995; Politis 2016), space precludes full engagement with these issues here. We nevertheless acknowledge that present behaviours may diverge from past ones for a wide variety of reasons incorporating both cultural and environmental factors. With regards to method, this (to us) reinforces the need to develop independent physical proxies which can clearly link certain behaviours to particular physical manifestations; whether in the past or present. In terms of shellfishing, these physical markers are primarily found in the processing and discard phases. The following section discusses these phases as part of the overall stages of shellfishing whilst also outlining the recurring themes recorded from ethnographic studies on Indo-Pacific shellfishing practices.

\section{Shellfishing in the Indo-Pacific}

\section{Recurring themes}

Numerous ethnographical studies have recorded modern shellfishing practices around the world, each focusing on certain aspects, such as exploitation pressure (see de Boer et al. 2000; Hockey et al. 1988); site formation definitions (see Bailey 1993; Balme 1995; Bird et al. 2002); species selection (see Attenbrow 1992; Balme 1995; Carter 2014; Catterall and Poiner 1987; Hardy et al. 2016; Meehan 1982); gathering time and catch size (see de Boer et al. 2002; Voorhies and Martínez-Tagüeńa 2016); behavioural ecology (see Macintosh et al. 2002; Thomas 2002); cooking techniques (see Aldeias et al. 2016); and gender roles (see Attenbrow 1992; Bird and Bird 2000; Jones 2009; Malm 2009). In Oceania, the initial ethnoarchaeological studies on modern fishing (see Kirch 1976; Kirch and Yen 1982) showed the importance and potential of ethnoarchaeology, however these early studies did not record substantive and quantitative data on labour and time or the consequent yield (Ono 2010). Over time, however, the methods of recording quantitative shellfish yields have improved (e.g. Thomas 2002) and some more recent studies have produced wide-ranging datasets. Betty Meehan's $(1982,1988)$ work in northern Australia, for example, is one of the most comprehensive ethnographic studies of shellfishing in the world and is frequently cited by other archaeologists. It covers gathering and processing practices of the Anbarra people, along with some basic discard practices that are primarily dependent on the location and size of camps. 
The role of men, women and children in exploiting marine resources represents a recurring theme of study in the region. In Oceania, gathering shellfish is an activity usually done by groups of women and children (Bird and Bird 1997, 2000; Bird et al. 2004; Jones 2009; Malm 2009; Meehan 1982), but men also go shellfishing on occasion (Malm 2009; Meehan 1982; Katherine Szabó, pers. obs. Langalanga Lagoon 2016). Similarly, women go fishing from time to time, even if it is an activity usually done by men. Nevertheless, in the Solomon Islands women dominate the shellfishing niche (Kruijssen et al. 2015). These issues are important since differing foraging strategies between children and adults can affect how a shell midden will appear in the archaeological record (Bird and Bird 2000). Such influence was documented by Attenbrow (1992), who used Meehan's observation of targeting extra species for variety as well as the children's role in collecting multiple species of varying sizes as a way to help distinguish between shell bed and shell midden sites in New South Wales.

Another recurring pattern in shellfishing studies is the range of particular shell species targeted in the Indo-Pacific region. Large, high-return shell taxa like Tridacna, Anadara and Polymesoda appear to have been preferred across a range of study sites and geographic areas (Bird et al. 2004; Carter 2014; Meehan 1982; Swadling and Chowning 1981:159; Thomas 2002:200). Marcia hiantina (formerly Tapes hiantina) was actively preferred by the Anbarra people compared to other species of shell (Meehan 1982). This gathering strategy focused on a single species is a conscious part of Anbarra behaviour (Meehan 1982:71). In contrast, at the Natunuku site in Viti Levu, Fiji, a suite of species were primary targets, with secondary and incidental species being collected when encountered (Szabó 2001). The tailored behaviours associated with species selection are an important aspect to consider in ethnoarchaeological studies, especially in terms of how they can impact upon the archaeological record.

\section{Stages of shellfishing}

The initial stage of shellfishing is gathering and has been a focus in all ethnographic studies in this region (e.g. Bird and Bird 1997, 2000; Bird et al. 2004; Carter 2014; Malm 2009; Meehan 1982; Swadling and Chowning 1981; Thomas 2002). Comparison of prehistoric and modern fishing practices are perceived as problematic (Ono 2010). Nowadays the time and labour component of gathering shells is still predominantly accomplished by hand. However, the use of modern knives would impact processing techniques and time, and metal pots and stoves would facilitate boiling and steaming. Motorised boats may also reduce the time taken to reach inshore and coral reef environments, but intertidal shellfish gathering is still constrained by the limited period of low tide during the day, which is dependent on seasonal and monthly cycles.

The second stage of processing shells can either be done in the field or the shellfish can be taken to be cleaned or cooked elsewhere (camp, home). Field processing can be dependent on the size of the catch as well as the species of shell, with large shells such as Tridacna and Lambis sometimes being recorded as processed at the point of collection (Bird et al. 2004; Meehan 1982; Thomas 2002). As Bird et al. (2002:467) state, 'field processing contributes to systematic and archaeologically detectable variability in shell middens', with the absence of evidence for large shellfish not necessarily signifying that they were not targeted and consumed. The shells that are transported back home to be processed are either boiled or roasted on fires (Bird et al. 2004; Meehan 1982). Meehan (1982:87-99) observes a number of different methods of cleaning and cooking shells, varying in terms of hearth constructions, heating methods and camp locations.

The final stage of shellfishing is discarding and has had little focus yet in ethnoarchaeological studies. Actual discard practices have only been explored briefly by studies undertaken by Beck (2007), Beck and Hill (2004), Bird et al. (2004) and Meehan (1982). Meehan (1982) separates the location of discard sites into dinnertime camps, home bases and processing sites. These site 
definitions have been reused by a number of archaeologists (Bailey 1993; Balme 1995; Bird et al. 2002; Ceci 1984; Clarke 1994; O'Connor and Veth 1993; Ulm 2006), but in doing so, uniformity of shellfish deposition and the behaviours underpinning these processes has been broadly assumed to be spatially, geographically and culturally consistent. Part of ethnoarchaeological research on Malaita, Solomon Islands, reported in this chapter was developed to test whether the depositional behaviours and resulting site types reported by Meehan could be transposed into other cultural and geographical contexts.

\section{Theoretical approaches}

When considering overall patterns of shellfish collection, different theoretical frameworks can be used to interpret foraging behaviours. Work by Frank Thomas (2002) in the Kiribati Islands, for example, focused on foraging behaviours through the lens of central place foraging and prey choice foraging models. Based on these models, it is argued that decisions about shellfish culling and transport can be predicted through prey attributes within a cost/benefit framework (Thomas 2002:182).

Research in the Torres Strait focused on the shellfish gathering and processing practices of the Meriam people and paired these ethnographic observations with central place foraging theory (Bird and Bird 1997, 2000; Bird et al. 2002, 2004). Bird and Bird (1997:53) found that midden sites varied depending on resource processing characteristics and foraging range. Their research among the Meriam aimed to understand the factors that influence subsistence behaviour rather than assume them as analogous to those of the past (Bird and Bird 1997:54). They highlighted that the variability in modern Meriam shell deposition is patterned in predictable ways due to subsistence decisions, which are anticipated by central place foraging models (Bird and Bird 1997:54).

\section{Ethnoarchaeological fieldwork in the Solomon Islands}

The main aim of our ethnoarchaeological fieldwork in the Solomon Islands was to observe and record the progression of shellfishing subsistence (from gathering, to processing and final discard) in a region with differing landscapes and culture than previous ethnographic studies in northern Australia (Meehan 1982), the Torres Strait (Bird and Bird 1997, 2000) and western Kiribati (Thomas 2002). By observing the entire progression of shellfishing (Figure 10.2), we hoped to pinpoint and identify any behaviour that left physical markers on the shell material, which could then be linked to similar traces on archaeological shell. This study highlights the specific stages where certain physical markers may manifest.

Fieldwork was undertaken on the island of Malaita, at Langalanga Lagoon (south-west) and Lau Lagoon (north-east). Both of these lagoons are dotted with artificial islands that have been deliberately built up using limestone, shell and coral blocks. Langalanga is a sheltered and calm lagoon with natural outer islands and a barrier reef protecting the inner natural and artificial islands, and coastline (Figure 10.3). Lau Lagoon is generally shallower, but larger, with prevalent easterly winds coming in from the Pacific Ocean. At Langalanga Lagoon it was necessary to canoe over to a larger island at the edge of the reef to go shellfishing, whereas at Lau Lagoon you only needed to follow the ocean retreating at low tide. At Lau, it was also possible to walk to some of the closer artificial islands when the tide was low enough. Mangrove habitats can be found on larger islands or along the coastline at both lagoons, including some deliberately planted plots in Langalanga Lagoon. Although each lagoon has its geographic singularities, both have a range of mangrove, rocky shore and reef environments that are abundant in shellfish. 
Gathering
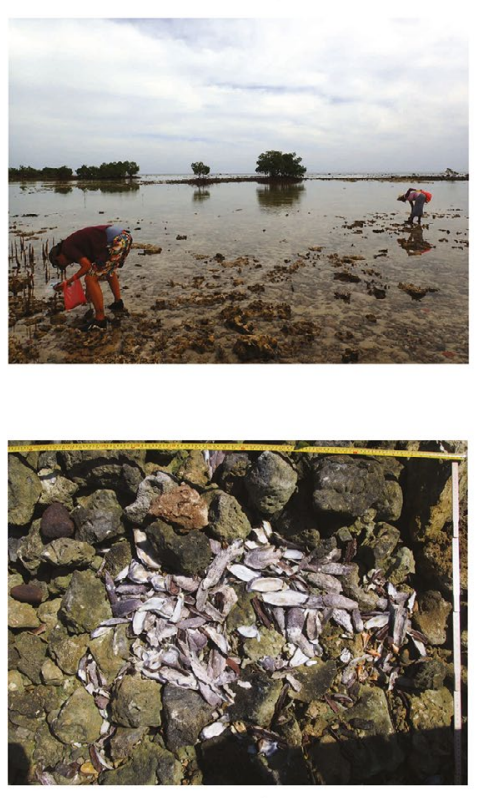

Discard
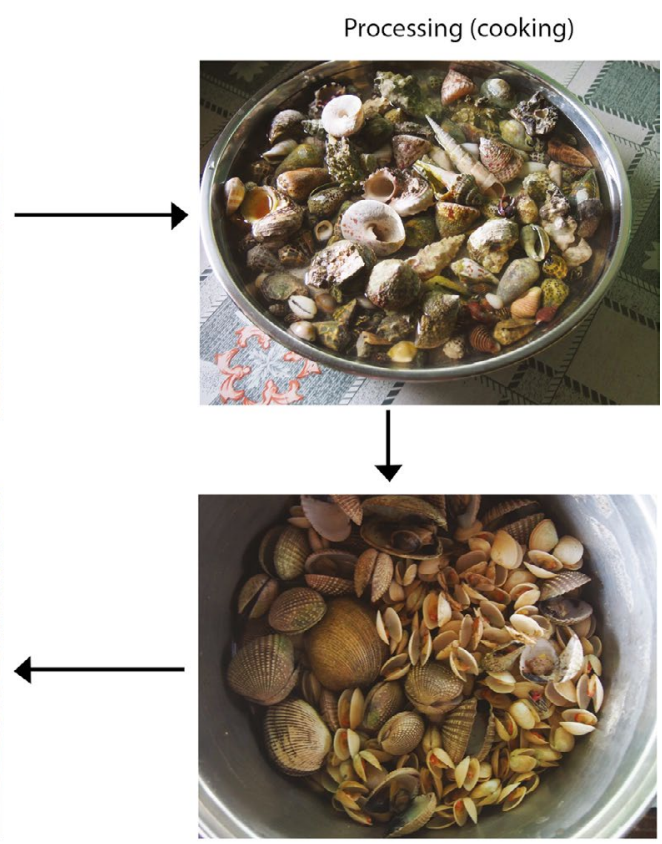

Processing (removing meat)

Figure 10.2. Photos of the shellfishing stages from gathering, processing and discard. Source: Annette Oertle and Katherine Szabó.

Langalanga Lagoon, western side of Malaita

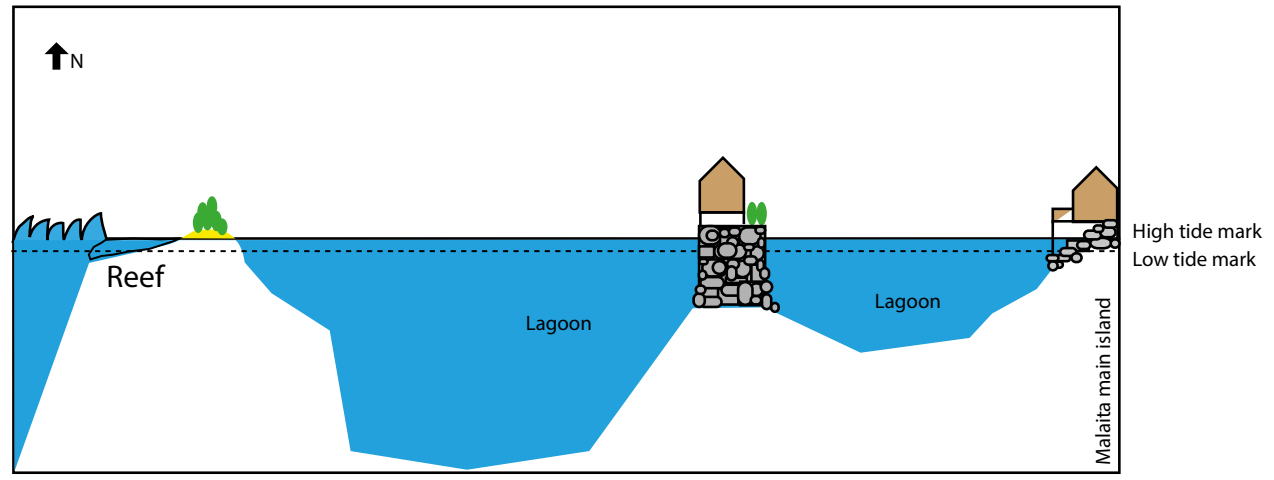

Lau Lagoon, eastern side of Malaita

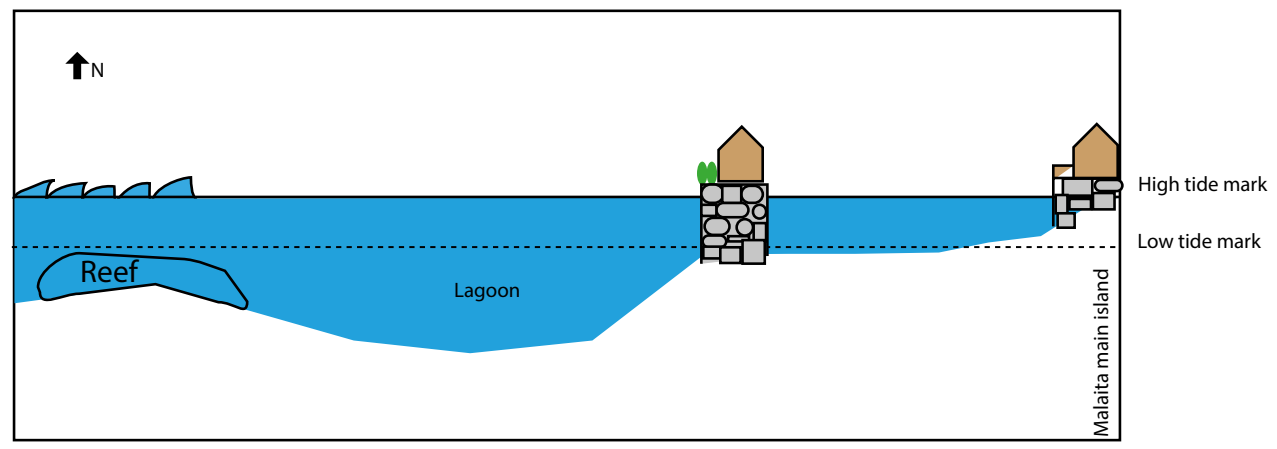

Figure 10.3. Langalanga and Lau lagoons, geography and environmental differences.

Source: Annette Oertle. 


\section{Gathering}

Shellfish gathering occurred during low tide at both lagoons. Mangrove and intertidal reef habitats were targeted as they were both close to villages and contained diverse and rich shellfish populations. Behaviours regarding shellfish gathering in the Solomon Islands tended to be comparable to other studies. More explicitly, collecting shellfish was a practice generally undertaken by women and children, although men were observed on occasion to be subsistencegathering as well as collecting shellfish for sale. Both bivalves and gastropods were collected and taken home. A range of shell species was targeted, with size being variable but focused on adult shells. As other studies have mentioned (see Meehan 1982; Swadling and Chowning 1981), children usually gathered Atactodea striata in the high-water mark beach grit due to the ease of sifting their fingers through the sand to find handfuls of this small bivalve close to the surface. When going out to gather shellfish in Langalanga, the number of accompanying gatherers (women and/or children) was primarily based on how many people could fit into a dugout canoe, whereas at Lau Lagoon the number of women and children going out to gather was less restricted due to the ease of access.

The method of gathering shells was consistent at both lagoons: shells were picked up by hand and placed in a bag or bucket (e.g. plastic, fabric or woven). None of the targeted shells needed a tool to pry from a rock (for example, limpet species). Instead, shells were easily picked up from the sand/mud or gently plucked from a rock. A stick or other pointed implement was usually used when digging out Anadara antiquata from the mud, as the shell is covered in fine bristles which can become embedded in fingers (Florence Kabi, Lau Lagoon, pers. comm. 2016). These shells are positioned in the substrate with their hinge facing upwards and can be visible through a small hole/depression in the substrate. On the reef flats gastropods were easily spotted during low tide, hiding in pools of water or in between rocks. Loose rocks were pushed over to reveal various gastropods like Nerita spp. and Thais spp. hiding in the shade. Other major taxa targeted for collection are summarised in Table 10.1.

Table 10.1. Species collected from lagoons, Malaita, Solomon Islands.

\begin{tabular}{|l|l|}
\hline Gastropods & Bivalves \\
\hline Lambis lambis & Anadara antiquata \\
\hline Trochus/Tectus spp. & Gafrarium tumidum \\
\hline Turbo spp. & Gafrarium pectinatum \\
\hline Drupa spp. & Geloina expansa \\
\hline Thais spp. & Periglypta spp. \\
\hline Nerita spp. & Chama spp. \\
\hline Cypraea/Monetaria spp. & Atactodea striata \\
\hline Conidae spp. & Ostreidae \\
\hline Polinices/Natica spp. & \\
\hline Haliotis spp. & \\
\hline
\end{tabular}

Source: Authors' summary. 


\section{Processing}

The processing stage of shellfishing included cleaning and cooking, which was accomplished through separation and boiling. Roasting was occasionally done for certain taxa of shell such as Turbo spp., however the primary method of cooking shellfish was by boiling. Whether this is a recent method of cooking due to the introduction of metal pots is unclear as there is no archaeological evidence of prehistoric or historic ceramic use on Malaita (Sheppard and Walter 2006:52). Once the catch was taken back home, the shells were separated out into bivalves and gastropods. Some bivalves were kept in freshwater for a short period to clean out the sand from their digestive tracts. All the shellfish were cooked before eating with bivalves boiled in one pot and gastropods in another. This was due to the greater time it took to cook the gastropods. The bivalves were cooked when the valves opened (5-10 minutes), whilst the gastropods took 15-20 minutes to cook. Individual shell cooking time was also dependent on the species and size. We observed no on-site processing of shellfish.

After cooking, gastropods had to be cleaned and the guts removed before eating, whereas bivalves could be eaten straight away. To remove the meat from Turbo spp., the shell was given a light tap on a hard surface then, with a sharp flick of the wrist, the entire animal and operculum came away. No tool was required. With other gastropods with opercula (such as Nerita spp.), a small twig or plant stem was used to remove the opercula and pry the meat out. The meat from some gastropod shells, like Lambis spp., could not be easily removed so the shells had to be broken to get inside (Figure 10.4). This breakage was focused on the dorsal area of the body whorl and actioned by holding the shell in hand and striking with a rock. Breakage was also necessary for Cypraea and Conus shells. These consistent breakage patterns can be linked to fragmented archaeological shell material based on shell species, location of breakage and the shape of the broken edge and thus assist in identifying processing techniques archaeologically. This is particularly useful to indicate whether shell breakage patterns reveal meat extraction or artefact production.

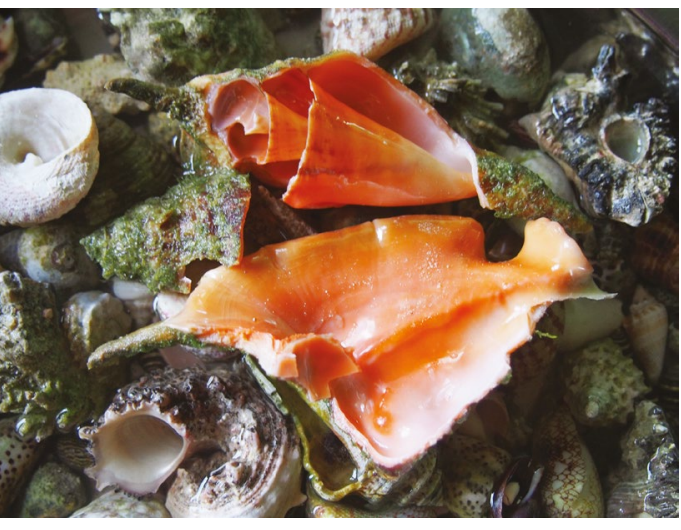

Figure 10.4. Breakage patterns on Lambis lambis from processing.

Source: Annette 0ertle.

\section{Discard}

The final stage of shellfishing is the disposal of the leftover shell material. Once discarded, the shell moves into the archaeological context. The shell refuse was kept together in a pot or bucket once the meat was removed. Any remaining entrails or non-calcareous opercula were fed to the chickens or pigs. At Langalanga the smaller shell pieces were used as infill for the artificial islands. This has stratigraphic implications for the anthropogenic islands themselves as the fragments trickle through the wide interstices between coral blocks.

Modern refuse was located away from buildings and out of the way of high traffic areas. Such areas included vegetated corners, edges of garden beds, corners of piers, into the lagoon and in the edges of mangrove stands. Shell discard was also left in the open and only covered or disturbed by more shell discard, falling leaf litter or incoming tides. Shell concentrations were discrete and scattered around various houses and gardens. The majority of shell concentrations were from single discard events. Concentrations located in mangrove beds, on piers or thrown into the lagoon were dispersed or covered in mud relatively quickly. Shell concentrations located in garden beds or near vegetation were relatively undisturbed environmentally but human or animal agents were the main vectors of disturbance. Terrestrial hermit crabs were 
also movers of discarded gastropods, leaving their old shell behind (see Szabó 2012). This was seen on numerous nightly wanderings where recently discarded gastropods had been quickly occupied by hermit crabs and were wandering around the gardens.

\section{Discussion}

Modern shellfishing behaviours highlight the roles of women and children in gathering shellfish. They have specific knowledge of the habitat and know the methods for finding different species. This is also seen in the various ways to clean and cook shell. The stages of processing and discard provide the greatest potential for physical markers on shell material and therefore for obtaining a better understanding of archaeological site formation and transformation. Cooking methods such as roasting can provide physical and chemical markers which can remain through to the archaeological record. It is well understood that heating of bone or rock will affect the microstructure and biochemistry of the material, but understanding of the response of shell to heating, on the other hand, is poor. A handful of recent studies (Aldeias et al. 2016; Milano et al. 2016) will complement burning experiments undertaken during fieldwork in the Solomon Islands to attempt to better understand these changes.

In terms of discard, the locations of midden deposits are very discrete with a low possibility of in situ preservation considering Indo-Pacific environmental factors. Large-scale environmental events are common in the Indo-Pacific (such as earthquakes, tsunamis and cyclones) and have a significant impact on human behaviour, resource availability, as well as archaeological site locations and preservation. Solomon Islanders have witnessed first-hand the effects of modern sea-level rise with a number of islands now gone or impacted by shoreline recession (Albert et al. 2016). First-hand accounts from people living in Langalanga and Lau lagoons mention a number of small islands, both natural and artificial, which have slowly decreased in size or been destroyed by cyclones. Residents have also noted changes in mangrove and reef zones due to sea-level rise. Smaller-scale environmental changes such as increased wave action, sediment build-up, bioturbation and bioerosion also influence the preservation of archaeological shell material. The separation of shell refuse (smaller shells for infill dropped into the gaps between coral blocks on artificial islands and shoreline extensions) and the differing locations where they are discarded minimises the likelihood of site preservation. If it had been done in the past, this form of shell discard as island infill would cause serious issues for archaeologists due to the constant addition, movement and removal of sand, shells and rock involved in the creation and life cycle of an artificial island. All contextual information about the discard of a shell would be impossible to know. Using discarded shell material as infill for island building in the Solomon Islands may also be a contributing factor in the minimal number of preserved coastal archaeological sites recorded for this region.

It is also important to remember that not all archaeological shell material in a site is likely to be food refuse. Malaita is the only remaining hub of shell money production in the Solomon Islands (Guo 2006) and fragmented or broken shell representing industrial debris from shell money production may be found in archaeological sites. Another possible concentration of fragmented gastropods may be formed as refuse from hermit crab extraction. This was observed in Langalanga Lagoon where every afternoon a woman would gather hermit crabs in the mangroves next to her house. She would then take them back to a rocky outcrop at the edge of the mangroves to smash them open, remove the hermit crabs and then use them as bait for fishing. The broken shells were left there, just above the high tide mark. Heavy rains or higher than normal waves would most likely wash them away. 


\section{Conclusion}

The issues involved in projecting modern human behaviours onto past societies are well recognised, but we can attempt to disentangle it by using a combination of scientific methods. Every aspect of shellfishing needs to be understood to minimise assumptions and strengthen inferences based on archaeological material. It is thus necessary to consider the varying nature of shellfishing in terms of variability in prey choice, field processing and transportation, but it is also essential to assess how these factors affect site formation. Ethnoarchaeology must also concentrate on discard and formation processes (Davidson 1988:29) as they provide a connection between the systemic and the archaeological record. If we can understand more of the life history behind an archaeological object, we can piece together the past with greater clarity. It is also important not to overlook the variability of human behaviour. A model that has great explanatory power in one location may not translate so well to others and the distinct differences in shell discard between Meehan's iconic Anbarra studies and those noted for Malaita serve to demonstrate this.

The short amount of time spent observing modern shellfishing practices at two different lagoons on Malaita, Solomon Islands has highlighted the need to follow and record the progression of shellfish gathering, processing and discard. The specific methods of processing shell can leave physical markers on shell material, whilst the distribution of shell discard and an understanding of the environmental impacts on site preservation in this tropical island region provide a valuable background in understanding how an archaeological site would form and transform over time.

\section{Acknowledgements}

Annette Oertle is a recipient of a National Geographic Young Explorers Grant (9854-16) and Katherine Szabó is a recipient of an Australian Research Council Future Fellowship (FT140100504), which funded fieldwork in the Solomon Islands.

Thanks to the Solomon Island National Museum, in particular Tony Heorake and Edna Belo who provided valuable assistance. This study was not possible without the assistance of Serah Kei and Philemon Bulu at Langalanga Lagoon and Florence Kabi at Lau Lagoon. We wish to thank the two anonymous reviewers as well as the editors. This research was conducted under a Solomon Islands Research Permit sponsored by the National Museum of the Solomon Islands and University of Wollongong Human Research Ethics approvals HE16/230 and HE16/228.

\section{References}

Albert, S, JX Leon, AR Grinham, JA Church, BR Gibbes and C Woodroffe. 2016. 'Interactions between sea-level rise and wave exposure on reef island dynamics in the Solomon Islands'. Environmental Research Letters 11:1-9. doi.org/10.1088/1748-9326/11/5/054011.

Aldeias, V, S Gur-Arich, R Maria, P Monteiro and P Cura. 2016. 'Shell we cook it? An experimental approach to the microarchaeological record of shellfish roasting'. Archaeological and Anthropological Sciences $1-19$.

Attenbrow, V. 1992. 'Shell bed or shell midden'. Australian Archaeology 34:3-21. doi.org/10.1080/03122 417.1992.11681447.

Bailey, G. 1993. 'Shell mounds in 1972 and 1992: Reflections on recent controversies at Ballina and Weipa'. Australian Archaeology 37:1-18. doi.org/10.1080/03122417.1993.11681491. 
Balme, J. 1995. '30,000 years of fishery in western New South Wales'. Archaeology in Oceania 30 (1):1-21. doi.org/10.1002/j.1834-4453.1995.tb00324.x.

Beck, ME. 2007. 'Midden formation and intrasite chemical patterning in Kalinga, Philippines'. Geoarchaeology: An International Journal 22 (4):453-475. doi.org/10.1002/gea.20161.

Beck, ME and ME Hill Jr. 2004. 'Rubbish, relatives and residence: The family use of middens'. Journal of Archaeological Method and Theory 11 (3):297-333. doi.org/10.1023/B:JARM.0000047316.02424.7c.

Bird, DW and RB Bird. 2000. 'The ethnoarchaeology of juvenile foragers: Shellfishing strategies among Meriam children'. Journal of Anthropological Archaeology 19:461-476. doi.org/10.1006/jaar.2000.0367.

Bird, DW and RLB Bird. 1997. 'Contemporary shellfish gathering strategies among the Meriam of the Torres Strait Islands, Australia: Testing predictions of central place foraging model'. Journal of Archaeological Science 24:9-63.

Bird, DW, RB Bird and JL Richardson. 2004. 'Meriam ethnoarchaeology: Shellfishing and shellmiddens'. Memoirs of the Queensland Museum, Culture 3 (1):183-197.

Bird, DW, JL Richardson, PM Veth and AJ Barham. 2002. 'Explaining shellfish variability in middens on the Meriam Islands, Torres Strait, Australia'. Journal of Archaeological Science 29:457-469. doi.org/ 10.1006/jasc.2001.0734.

Carter, M. 2014. 'Subsistence shell fishing in NW Santa Isabel, Solomon Islands: Ethnoarchaeology and the identification of two Polymesoda (Solander 1786) species'. Ethnoarchaeology 6(1):40-60. doi.org/ 10.1179/1944289013Z.00000000013.

Catterall, CP and IR Poiner. 1987. 'The potential impact of human gathering on shellfish populations, with reference to some NE Australian intertidal flats'. OIKOS 50(1):114-122. doi.org/10.2307/ 3565407.

Ceci, L. 1984. 'Shell midden deposits as coastal resources'. World Archaeology 16 (1):62-74. doi.org/ 10.1080/00438243.1984.9979916.

Claassen, C. 1998. Shells. Cambridge: Cambridge University Press.

Clarke, AN. 1994. 'Winds of change: An archaeology of contact in the Groote Eylandt archipelago, Northern Australia'. Unpublished PhD thesis, The Australian National University, Canberra.

Cunningham, JJ and S MacEachern. 2016. 'Ethnoarchaeology as slow science'. World Archaeology 48 (5):628-641. doi.org/10.1080/00438243.2016.1260046.

David, N and C Kramer. 2001. Ethnoarchaeology in action. Cambridge: Cambridge University Press. doi.org/10.1017/CBO9781316036488.

Davidson, I. 1988. 'The naming of parts: Ethnography and the interpretation of Australian prehistory'. In Archaeology with ethnography: An Australian perspective, edited by B Meehan and R Jones, 17-32. Canberra: Department of Prehistory, Research School of Pacific Studies, The Australian National University.

de Boer, WF, AF Blijdenstein and F Longamane. 2002. 'Prey choice and habitat use of people exploiting intertidal resources'. Environmental Conservation 29 (2):238-252. doi.org/10.1017/ S0376892902000140.

de Boer, WF, T Pereira and A Guissamulo. 2000. 'Comparing recent and abandoned shell middens to detect the impact of human exploitation on the intertidal ecosystem'. Aquatic Ecology 34:287-297. doi.org/10.1023/A:1009957409421. 
Faulkner, P. 2006. 'The ebb and flow: An archaeological investigation of late Holocene economic variability on the coastal margin of Blue Mud Bay, Northern Australia'. Unpublished PhD thesis, The Australian National University, Canberra.

Gould, RA and PJ Watson. 1982. 'A dialogue on the meaning and use of analogy in ethnoarchaeological reasoning'. Journal of Anthropological Archaeology 1:355-381. doi.org/10.1016/0278-4165(82)90002-2.

Guo, PY. 2006. 'From currency to agency: Shell money in contemporary Langalanga, Solomon Islands'. Asia-Pacific Forum 31:17-38.

Hardy, K, A Camara, R Piqué, E Dioh, M Guéye, HD Diadhiou, M Faye, H Diaw and M Carre. 2016. 'Shellfishing and shell midden construction in the Saloum Delta, Senegal'. Journal of Anthropological Archaeology 41:19-32. doi.org/10.1016/j.jaa.2015.11.001.

Hockey, PAR, AL Bosman and WR Siegfried. 1988. 'Patterns and correlates of shellfish exploitation by costal people in Transkei: An enigma of protein production'. Journal of Applied Ecology 25 (1):353-363. doi.org/10.2307/2403631.

Jimenez, H, P Dumas, M Léopold and J Ferraris. 2011. 'Invertebrate harvesting on tropical urban areas: Trends and impact on natural populations (New Caledonia, South Pacific)'. Fisheries Research. 108 (1):195-204. doi.org/10.1016/j.fishres.2010.12.021.

Jones, S. 2009. Food and gender in Fiji: Ethnoarchaeological explorations. Lanham, Maryland: Lexington Books.

Kirch, PV. 1976. 'Ethno-archaeological investigations in Futuna and Uvea (Western Polynesia): A preliminary report'. Journal of the Polynesian Society 85:27-69.

Kirch, PV and DE Yen. 1982. Tikopia: The prehistory and ecology of a Polynesian outlier. B.P. Bishop Museum Bulletin 238. Honolulu: Bishop Museum.

Kruijssen, F, J Albert, M Morgan, D Boso, F Siota, S Sibiti and A Schwarz. 2015. 'Livelihoods, markets and gender in Solomon Islands: Case studies from Western and Isabel Provinces'. SPC Women in Fisheries Information Bulletin 26:24-36.

Macintosh, DJ, EC Ashton and V Tansakul. 2002. 'Utilisation and knowledge of biodiversity in the Ranong Biosphere Reserve, Thailand'. ITCZM Monograph 7:1-30.

Malm, T. 2009. 'Women of the coral gardens: The significance of marine gathering in Tonga'. SPC Traditional Marine Resource Management and Knowledge Information Bulletin 25:2-15.

Meehan, B. 1982. Shell bed to shell midden. Canberra: Australian Institute of Aboriginal Studies.

Meehan, B. 1988. 'The "Dinnertime Camp"'. In Archaeology with ethnography: An Australian perspective, edited by B Meehan and R Jones, 171-181. Canberra: Department of Prehistory, Research School of Pacific Studies, The Australian National University.

Milano, S, AL Prendergast and BR Schöne. 2016. 'Effects of cooking on mollusk shell structure and chemistry: Implications for archaeology and paleoenvironmental reconstruction'. Journal of Archaeological Science: Reports 7:14-26. doi.org/10.1016/j.jasrep.2016.03.045.

O'Connell, JF. 1995. 'Ethnoarchaeology needs a general theory of behavior'. Journal of Archaeological Research 3:205-255. doi.org/10.1007/BF02231450.

O'Connor, S and P Veth. 1993. 'Where the desert meets the sea: A preliminary report of the archaeology of the southern Kimberley coast'. Australian Archaeology 37:25-34. doi.org/10.1080/03122417.1993. 11681493.

Ono, R. 2010. 'Ethno-archaeology and early Austronesian fishing strategies in near-shore environments'. Journal of the Polynesian Society 119:269-314. 
Politis, GG. 2016. 'The role and place of ethnoarchaeology in current archaeological debate'. World Archaeology. 48 (5):705-709. doi.org/10.1080/00438243.2016.1230516.

Schiffer, MB. 1972. 'Archaeological context and systemic context'. American Antiquity 37 (2):156-165. doi.org/10.2307/278203.

Sheppard, PJ and R Walter. 2006. 'A revised model of Solomon Islands culture history'. Journal of the Polynesian Society 115:47-76.

Sinopoli, CM. 1991. 'Seeking the past through the present: Recent ethnoarchaeological research in South Asia'. Asian Perspectives 30 (2):177-192.

Swadling, P and A Chowning. 1981. 'Shellfish gathering at Nukalau Island, West New Britain Province, Papua New Guinea'. Journal de la Société des océanistes 72-73 (37):159-167. doi.org/10.3406/ jso. 1981.3057.

Szabó, K. 2001. 'The reef, the beach and the rocks: An environmental analysis of mollusc remains from Natunuku, Viti Levu, Fiji'. In The archaeology of Lapita dispersal in Oceania: Papers from the Fourth Lapita Conference, June 2000, Canberra, Australia, edited by GR Clark, AJ Anderson and T Vunidilo, 159-166. Terra Australis 17. Canberra: Pandanus Books.

Szabó, K. 2012. 'Terrestrial hermit crabs (Anomura: Coenobitidae) as taphonomic agents in circumtropical coastal sites'. Journal of Archaeological Science 39:931-941. doi.org/10.1016/j.jas.2011.10.028.

Thomas, FR. 2002. 'An evaluation of central-place foraging among mollusk gatherers in Western Kiribati, Micronesia: Linking behavioural ecology with ethnoarchaeology'. World Archaeology 34 (1):182-208. doi.org/10.1080/00438240220134313.

Ulm, S. 2006. Coastal themes: An archaeology of the southern Curtis Coast, Queensland. Terra Australis 24. Canberra: ANU E Press. doi.org/10.26530/OAPEN_458881.

Voorhies, B and N Martínez-Tagüeña. 2016. 'Clamming up: Ethnoarchaeological study of a Costa Rican artisanal clam fishery'. The Journal of Island and Coastal Archaeology 13:43-65. doi.org/10.1080/1556 4894.2016.1262483.

Waselkov, GA. 1987. 'Shellfish gathering and shell midden archaeology'. Advances in Archaeological Method and Theory 10:93-210. doi.org/10.1016/B978-0-12-003110-8.50006-2.

Wylie, A. 1985. 'The reaction against analogy'. Advances in Archaeological Method and Theory 8:63-111. doi.org/10.1016/B978-0-12-003108-5.50008-7. 
This text is taken from Archaeologies of Island Melanesia: Current approaches to landscapes, exchange and practice, edited by Mathieu Leclerc and James Flexner, published 2019 by ANU Press, The Australian National University, Canberra, Australia.

doi.org/10.22459/TA51.2019.10 